\title{
Short Sisal Fibers Reinforced Epoxy Resins: Tensile Strength
}

Petr Valášek

Department of Material Science and Manufacturing Technology, Faculty of Engineering, Czech University of Life Sciences Prague. Kamýcká 129, 165 21, Prague. Czech Republic. E-mail: valasekp@tf.czu.cz

Composite materials synergistically combine the properties of their sub-phases. Among the most widespread group of composite materials include fiber reinforced composites - usually with a polymer matrix. Mechanical properties of fiber composites are used in a variety of industries. The fibers can be represented by synthetic fibers or natural ones. Advantage of natural fibers is that it is a renewable resource, they are inexpensive, have adequate mechanical properties, which, however, due to the biological material may vary substantially. Described contribution deals with the experimental description of the tensile strength of two epoxy resins filled with short sisal fibers - random orientation of the fibers with different length, i.e. $2 \mathrm{~mm}, 4 \mathrm{~mm}$ and $6 \mathrm{~mm}$. This paper compares the composite systems prepared from epoxy resins with different viscosity (resins Glue Epox Rapid, Glue Epox Rapid F) by casting. The presence of short fibers of sisal without controlled interlayer statistically unchanged tensile strength in many cases, and also increased the modul of elasticity in all cases.

Keywords: Agave Sisalana, biocomposite, mechanical properties.

\section{Acknowledgement}

The results were supported by the grant IGA TF 2015 (31140/1312/3107): Optimizing of the properties of resins and adhesives filled with organic and anorganic microparticles determined with experimental approach.

\section{References}

[1] MIECK, K..P., NECHWATAL, A., KNOBELSDORF, C. (1994). Potential applications of natural fibres in composite materials. In: Melliand Textilberichte, Vol. 75, No. 11, pp 892-898.

[2] VALÁŠEK, P., MÜLLER, M. (2013). Changes of Polyurethane Mechanical Properties Filled with Glass Powder. In: Manufacturing Technology, Vol. 13, No. 4, pp. 563-568.

[3] VALÁŠEK, P., MÜLLER, M. (2012). Polymeric particle composites with filler saturated matrix. In: Manufacturing Technology, Vol. 12, No. 13, pp. $272-276$.

[4] MÜLLER, M., VALÁŠEK, P. (2012). Abrasive wear effect on Polyethylene, Polyamide 6 and polymeric particle composites. In: Manufacturing Technology, 12, pp. 55-59.

[5] MÜLLER, M. (2014). Setting of causes of adhesive bonds destruction by means of optical analysis. In: Manufacturing Technology, Vol. 14, No. 3, pp. 371-375.

[6] MÜLLER, M. (2013). Research of renovation possibility of machine tools damage by adhesive bonding technology. In: Manufacturing Technology, Vol. 13, No. 4, pp. 504-509.

[7] BOOPALAN, M., UMAPATHY, M.J., JENYFER, P. (2012). A Comparative Study on the Mechanical Properties of Jute and Sisal Fiber Reinforced Polymer Composites. In: Silicon, pp. 145-149.

[8] MARSH, G. (2003). Next step for automotive materials.Iin: Materials today, Vol. 6, pp. 36-43.

[9] BLEDZKI, A.K., GASSAN, J. (1999). Composites reinforced with cellulose based fibres. In: Progress in Polymer Science, Vol. 24, No. 2, pp. 221-274.

[10] FERREIRA, F.C., CURVELO, A.A.S., MATTOSO L.H.C. (2003). Preparation and characterization of benzylated sisal fibers. In: J. Appl. Polym. Sci., Vol. 89, No. 11, pp. 2957-2965.

[11] MONTEIRO, S.N., et al. (2012). Tensile properties of epoxy composites reinforced with continuous sisal fibers. In: Materials Science Forum, Vol. 775-776, pp. 284-289.

[12] JEYARAJ, P., RAJINI, N., SIVA, I., SENTHILKUMAR, K. (2015). Effect of fibre length and weight percentage on mechanical properties of short sisal/polyester composite International. In: Journal of Computer Aided Engineering and Technology, Vol. 7, No. 1, pp. 60-71.

[13] SENTHILKUMAR, K., et al. (2015). Effect of fibre length and weight percentage on mechanical properties of short sisal/polyester composite. In: International Journal of Computer Aided Engineering and Technology, Vol. 7, No. 1, pp. 60-71.

[14] HAQUE, R., ET AL. (2015). Fibre-matrix adhesion and properties evaluation of sisal polymer composite. In: Fibers and Polymers, Vol. 16, No. 1, pp. 146-152. 